\title{
Expression of cancer testis antigens and its correlation with clinicopathological parameters in hepatocellular carcinoma
}

Meng Wang ${ }^{1,2^{*}}$, Xin-feng Chen ${ }^{2,6}$, Zhi-qin Li ${ }^{3}$, Zhen Zhang ${ }^{2,6}$, Dong-li Yue ${ }^{2,6}$, Yan-hong Liu', Dong Jiang ${ }^{1}$, Yu-ling Sun ${ }^{4}$, Yong-fu Zhao ${ }^{4}$, Shu-huan $\mathrm{Wu}^{3}$, Jian-sheng $\mathrm{Li}^{1}$, Yi Zhang ${ }^{2,5,6}$

From Society for Immunotherapy of Cancer 28th Annual Meeting

National Harbor, MD, USA. 8-10 November 2013

\section{Background}

Many therapies such as surgery, chemical or physical approaches have been used for treatment of HCC; however, the outcome is still poor. Cancer immunotherapy is considered to be one of the promising strategies in recent years.

\section{Methods}

Expression of CTAs genes including MAGE A3, MAGE A4, MAGE C2 and NY-ESO-1 genes was detected with reverse transcription polymerase chain reaction (RTPCR) in HCC tissues and corresponding adjacent noncancerous tissues from 71 HCC patients.

\section{Results}

87.3\% of HCC tumor tissue samples expressed at least 1 CTAs. HCC adjacent non-cancerous tissues did not express CTAs. 78.9\% tumor tissue samples expressed MAGE-A3 mRNA, 33.8\% samples expressed MAGE-A4 mRNA, 74.6\% samples expressed MAGE-C2 mRNA and $14.1 \%$ samples expressed NY-ESO-1 mRNA. The expression of CTAs showed correlation with $\mathrm{Ki} 67(\mathrm{r}=0.27$, $\mathrm{P}=0.02)$ and tumor stages $(\mathrm{r}=0.31, \mathrm{P}=0.01)$, no correlation with clinical parameters such as age, gender, ALT, HLAA2 positive, CA125, CA199, HBV or HCV infection and tumor size $(P>0.05)$. The expression of MAGE-A3 showed correlation with the high expressions of CEA in serum $(r=0.30, P=0.03)$, AFP in serum $(r=0.26, P=0.03)$ and lymph node metastases $(\mathrm{r}=0.30, \mathrm{P}=0.01)$.
Table 1 Clinicopathological characteristics of the HCC patients

\begin{tabular}{|c|c|c|}
\hline Characteristics & No.patients & $\%$ \\
\hline Gender & 71 & \\
\hline Male & 54 & 76.1 \\
\hline Female & 17 & 23.9 \\
\hline \multicolumn{3}{|l|}{ Age(y) } \\
\hline$<55$ & 47 & 66.2 \\
\hline$\geq 55$ & 24 & 33.8 \\
\hline \multicolumn{3}{|l|}{ ALT(IU/ml) } \\
\hline$<80$ & 61 & 85.9 \\
\hline$\geq 80$ & 10 & 14.1 \\
\hline \multicolumn{3}{|l|}{ HLA A2 } \\
\hline Positive & 41 & 57.7 \\
\hline Negative & 30 & 42.3 \\
\hline \multicolumn{3}{|l|}{ AFP(ng/ml) } \\
\hline$\leq 10$ & 30 & 42.3 \\
\hline$>10$ & 41 & 57.7 \\
\hline \multicolumn{3}{|l|}{ Tumor size(cm) } \\
\hline$\leq 5$ & 43 & 60.6 \\
\hline$>5$ & 28 & 39.4 \\
\hline \multicolumn{3}{|c|}{ TNM classification } \\
\hline | or || & 34 & 47.9 \\
\hline III or IV & 37 & 52.1 \\
\hline \multicolumn{3}{|l|}{ Etiology } \\
\hline HBV & 45 & 63.4 \\
\hline $\mathrm{HCV}$ & 6 & 8.5 \\
\hline No & 20 & 28.1 \\
\hline
\end{tabular}

Ki67(\%) 
Table 1 Clinicopathological characteristics of the HCC patients (Continued)

\begin{tabular}{lcc}
\hline$\leq 40$ & 30 & 42.3 \\
$>40$ & 41 & 57.7 \\
CTAs & & \\
Positive & 62 & 87.3 \\
Negative & 9 & 12.7 \\
Average age(year) & $53.7 \pm 11.5$ & \\
\hline
\end{tabular}

\section{Conclusion}

Our findings demonstrate the cancer testis expression of CTAs genes show correlations with tumor stages and proliferation and may represent useful targets for tumor specific immunotherapy in HCC patients.

\section{Authors' details}

'Department of Gastroenterology, the First Affiliated Hospital of Zhengzhou University, Zhengzhou, China. ${ }^{2}$ Biotherapy Center, the First Affiliated Hospital of Zhengzhou University, Zhengzhou, China. ${ }^{3}$ Department of Infectious Diseases, the First Affiliated Hospital of Zhengzhou University, Zhengzhou, China. ${ }^{4}$ Department of Hepatobiliary Surgery, the First Affiliated Hospital of Zhengzhou University, Zhengzhou, China. ${ }^{5}$ Department of Bioengineering, the First Affiliated Hospital of Zhengzhou University, Zhengzhou, China.

${ }^{6}$ Department of Oncology, the First Affiliated Hospital of Zhengzhou University, Zhengzhou, China.

Published: 7 November 2013

doi:10.1186/2051-1426-1-S1-P250

Cite this article as: Wang et al: Expression of cancer testis antigens and its correlation with clinicopathological parameters in hepatocellular carcinoma. Journal for ImmunoTherapy of Cancer 2013 1(Suppl 1):P250.

Submit your next manuscript to BioMed Central and take full advantage of:

- Convenient online submission

- Thorough peer review

- No space constraints or color figure charges

- Immediate publication on acceptance

- Inclusion in PubMed, CAS, Scopus and Google Scholar

- Research which is freely available for redistribution

Submit your manuscript at www.biomedcentral.com/submit 